\title{
Differential characteristics of the early stage of lung inflammation induced by SARS-CoV Nucleocapsid protein related to age in the mouse
}

\author{
Y. G. Zhu, J. M. Qu* \\ Department of Pulmonary Medicine, Huadong Hospital, Shanghai 200040, China; Shanghai Medical School of Fudan University, Shanghai 200032, \\ China, e-mail: jmqu64@yahoo.com.cn
}

Received 25 March 2008; returned for revision 2 July 2008; received from final revision 24 November 2008; accepted by Graham R. Wallace 23 December 2008

Published Online First 22 February 2009

\begin{abstract}
Objective: Severe acute respiratory syndrome (SARS) is an acute infectious disease of the respiratory system which has newly emerged. Interestingly, it appears to be a disease that predominantly affects adults while the mortality in children is extremely low. However, the pathogenesis of SARS in relation to different characteristics relevant to age remains unclear.
\end{abstract}

Material and Methods: To better understand the role of cytokines in the immunopathological processes of SARS, weanling (4 weeks old), young (6 weeks old) and adult (10 weeks old) male BALB/C mice were inoculated intranasally with N-protein of SARS-CoV in this study. Serum or lung homogenate levels of some cytokines such as tumor necrosis factor- $\alpha$ (TNF- $\alpha$ ) and interferon- $\gamma$ (IFN- $\gamma)$ along with acute injury lung index and histology were also analyzed.

Results: Histopathological analysis of adult male BALB/ $\mathrm{C}$ mice after $\mathrm{N}$-protein infection showed progressive inflammatory reactions, especially pulmonary edema, in accordance with a moderately $(\sim 13 \%)$ elevated level of $\mathrm{W} / \mathrm{D}$ ratio at $24 \mathrm{~h}$. Although adult groups underwent a progressive lung inflammation in the acute phase accompanied by raised levels of TNF- $\alpha$ in serum, no significant changes in lung TNF- $\alpha$ level were reported simultaneously. Moreover, adult SARS infected BALB/c mice showed elevated levels of IFN- $\gamma$ while IFN- $\gamma$ levels in weanling and young groups had no obvious association with lung inflammation.

Conclusion: Our study supports the observation that adult mice do have progressively greater immune reactions than weanling and adolescent ones over time. The relative immaturity of the immune system in weanlings

*Corresponding author: J. M. Qu may confer benefit leading to less impairment of lung function. However, the measurement of TNF- $\alpha$ and IFN$\gamma$ levels was not indicative of the severity of lung injury at the early stage of disease.

Key words: Severe acute respiratory syndrome (SARS) $\mathrm{N}$-protein of SARS-CoV - TNF- $\alpha-$ IFN- $\gamma-$ Age

\section{Introduction}

Severe acute respiratory syndrome (SARS) is an acute infectious disease of the respiratory system. It is a new infectious disease with a significant morbidity and mortality, whose major clinical features include persistent fever, chills/rigor, myalgia, malaise, dry cough, headache, and dyspnoea. Interestingly, when it wreaked havoc in China, South East Asia and other parts of the world in 2003 , it appeared to be a disease that predominantly affects adults. Less than $10 \%$ of those infected were children. Among the affected children, only $5 \%$ required admission to an intensive care unit, and less than $1 \%$ required mechanical ventilation. No deaths were reported among children affected by SARS ${ }^{[1]}$. Different features in children have led some to believe that SARS is a relatively mild disease in this age group. A novel coronavirus has been identified as the pathogen responsible for SARS ${ }^{[2]}$. However, the pathogenesis of SARS involving different characters relevant to age remains unclear and there is no efficient treatment for SARS so far.

As previous studies showed, SARS-CoV contains a variable region representing 4 coding sequences for viral structural genes [spike (S protein), envelope (E protein), 

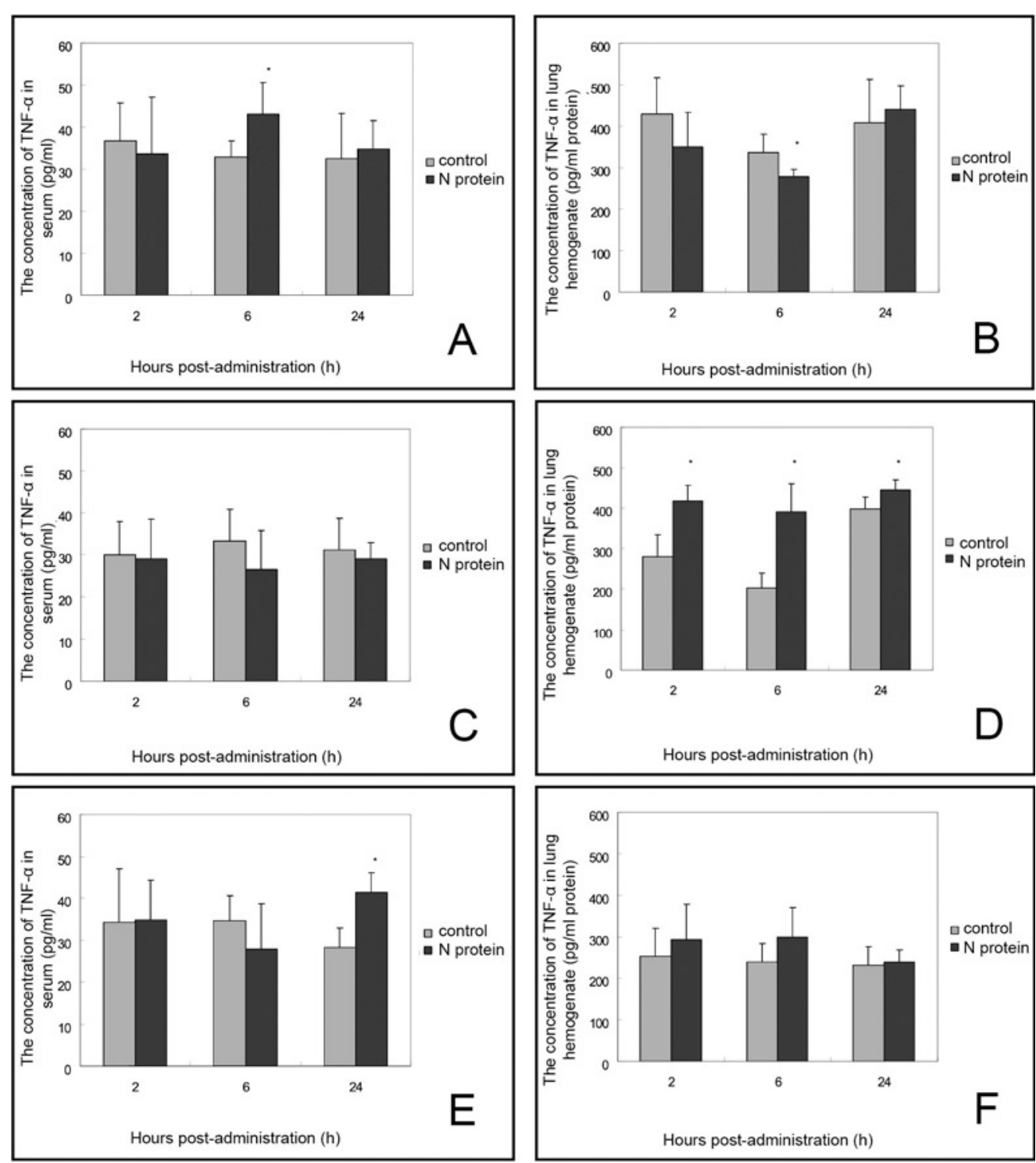

Fig 1. The concentration of TNF$\alpha$ in sera and lung homogenate samples of $\mathrm{N}$-protein groups $(n=6)$ compared with control groups $(n=6)$. (A) The concentration of TNF- $\alpha$ in sera of weanling mice. (B) The concentration of TNF- $\alpha$ in homogenates of weanling mice. (C) The concentration of TNF- $\alpha$ in sera of young mice. (D) The concentration of TNF- $\alpha$ in homogenates of young mice. (E) The concentration of TNF- $\alpha$ in sera of adult mice. (F) The concentration of TNF- $\alpha$ in homogenates of adult mice. *Significant differences between $\mathrm{N}$ protein groups and control groups, at $p<0.05$.

membrane (M protein), and Nucleocapsid ( $\mathrm{N}$ protein)], and the $\mathrm{COOH}$ terminus of the $\mathrm{N}$ protein could be extremely antigenic ${ }^{[3]}$. Among all the coronavirus proteins, the $\mathrm{N}$ protein is the most abundant throughout infection at both mRNA and protein levels ${ }^{[4]}$. Recently, several studies in animals demonstrated that the $\mathrm{N}$ protein could induce specific T-cell responses as have been observed with other coronaviruses, and it has also been proved that cellular immune response against $\mathrm{N}$ protein of coronavirus can generate protective effects ${ }^{[5,6,7]}$. In this study, we investigated the different manifestations of lung inflammation caused by $\mathrm{N}$ protein of SARS-CoV in mice.

The clinical manifestations, chest radiographic and pathological features of the patients with SARS are similar to those of acute lung injury (ALI) and acute respiratory distress syndrome (ARDS). Immunopathological injury of host cells triggered by the immune response to virus plays a key role in the pathogenesis of SARS.
Determination of cytokines which are involved in cell damage and development of organ dysfunction should aid our understanding of the immunopathological processes of SARS. It has been shown that many proinflammatory cytokines such as tumor necrosis factor- $\alpha(\mathrm{TNF}-\alpha)$ and interferon- $\gamma($ IFN- $\gamma)$ take part in the occurrence and development of ALI and ARDS, and the therapy, aimed directly at cytokines has achieved initial effects ${ }^{[8]}$. TNF- $\alpha$ has been shown to be elevated in bronchopulmonary secretions of patients with adult respiratory distress syndrome ${ }^{[9]}$, and to cause a pulmonary inflammatory reaction when administered intravenously or directly into the lungs of animals ${ }^{[10]}$. Although the production of TNF- $\alpha$ was found to increase and correlate positively with severity in H5N1 infections ${ }^{[11]}$ and swine pneumonia ${ }^{[12]}$, other studies showed that plasma TNF- $\alpha$ was not elevated in SARS patients ${ }^{[13,14]}$, which suggested that the host's immune reaction to the novel coronavirus might be dif- 
Table 1. Changes in leukocyte count in peripheral blood

\begin{tabular}{|c|c|c|c|c|c|c|}
\hline & $\begin{array}{l}4 \text { weeks (weanling) } \\
\text { Control }(n=6)\end{array}$ & N-protein $(n=6)$ & $\begin{array}{l}6 \text { weeks (young) } \\
\text { Control }(n=6)\end{array}$ & N-protein $(n=6)$ & $\begin{array}{l}10 \text { weeks (adult) } \\
\text { Control }(n=6)\end{array}$ & $\mathrm{N}$-protein $(\mathrm{n}=6)$ \\
\hline 2 hours & $4.13 \pm 2.06$ & $4.38 \pm 2.37$ & $2.97 \pm 1.47$ & $6.07 \pm 2.38^{*}$ & $2.97 \pm 1.12$ & $4.07 \pm 1.60$ \\
\hline 24 hours & $6.93 \pm 1.92$ & $5.76 \pm 1.78$ & $4.97 \pm 1.36$ & $3.72 \pm 0.94$ & $4.48 \pm 2.03$ & $7.14 \pm 2.90$ \\
\hline
\end{tabular}

Values are presented as mean $\pm \mathrm{SD}$.

*Significant differences between N-protein groups and control groups, at $p<0.05$.

Table 2. Changes in lung parenchyma histopathology scores (Congestion)

\begin{tabular}{lllllll}
\hline & $\begin{array}{l}\text { 4 weeks (weanling) } \\
\text { control }(\mathrm{n}=6)\end{array}$ & N-protein $(\mathrm{n}=6)$ & $\begin{array}{l}\text { 6 weeks (young) } \\
\text { control }(\mathrm{n}=6)\end{array}$ & N-protein $(\mathrm{n}=6)$ & $\begin{array}{l}10 \text { weeks (adult) } \\
\text { control }(\mathrm{n}=6)\end{array}$ & N-protein $(\mathrm{n}=6)$ \\
\hline 2 hours & $1.50 \pm 0.55$ & $2.17 \pm 0.75$ & $1.17 \pm 0.75$ & $2.00 \pm 0.63$ & $0.83 \pm 0.75$ & $1.33 \pm 0.52$ \\
6 hours & $1.33 \pm 0.82$ & $1.50 \pm 0.55$ & $1.33 \pm 0.82$ & $2.50 \pm 0.84^{*}$ & $1.17 \pm 0.75$ & $2.00 \pm 0.63$ \\
24 hours & $1.50 \pm 0.55$ & $2.33 \pm 0.82$ & $2.00 \pm 0.89$ & $2.17 \pm 0.75$ & $1.33 \pm 0.82$ & $2.67 \pm 0.82^{*}$ \\
\hline
\end{tabular}

Values are presented as mean \pm SD.

*Significant differences between N-protein groups and control groups, at $p<0.05$.

ferent from the immune reaction to other pathogens. Besides, imbalance of Th1/Th2 cytokine profile confirmed the SARS-CoV induced Th1 predominance as all SARS patients exhibited a significant increase in the typical antiviral Th1 cytokine IFN- $\gamma$ and an array of proinflammatory cytokines (IL-1 $\beta$, IL-6 and IL-12) ${ }^{[13]}$. Other studies showed that chemokines such as IFN- $\gamma$-inducible protein-10 (IP-10) and monokine induced by interferon- $\gamma$ were substantially boosted soon after the onset of fever in pediatric cases ${ }^{[17]}$. However, there is still some controversy or uncertainty about the expression pattern of cytokines in the development of SARS, especially in the early stage of the disease among different ages.

To understand the role of cytokines in the immunopathological processes of SARS better, the cytokine profiles in both serum and lung homogenate levels at defined stages in different ages were analyzed. Besides, the leukocyte count, wet/dry ratio of lung tissue and histology were also examined after administration.

\section{Materials and Methods}

\section{Animals}

Weanling (4 weeks old), young (6 weeks old) and adult (10 weeks old) male BALB/C mice, 36 of each, were obtained from the Department of Animal Husbandry in Shanghai Medical School of Fudan University. The animals were housed, six mice per standard cage, in a specified pathogen-free environment. All mice were maintained on a $12 \mathrm{hrs} \mathrm{light/}$ dark cycle and received water and food ad libitum. All experiments were approved by Experimental animal Ethics Committee of Fudan University.

\section{Administration of N-protein of SARS}

Mice in each range of age were randomly assigned to two groups: (1) Animals in experiment groups were anesthetized by ethylether and then inoculated intranasally ${ }^{[18,19]}$ with a dose of $0.5 \mathrm{mg} / \mathrm{kg}$ (in a volume of $1 \mathrm{ml} / \mathrm{kg}$ ) of N-protein of SARS derived from serum of SARS patient (Fudan Yueda Bio-tech co. Ltd) $(\mathrm{n}=18)$; (2) Normal control mice were inoculated intranasally with the same volume of $0.9 \%$ sodium chloride $(\mathrm{n}=18)$. In each group, there are three subsets which represented three observed time points ( 2,6 and 24 hours after administration) (6 mice for each subset) as individual mice do not survive multiple blood withdrawals. In each subset, mice were reanesthetized with ethylether and sacrificed by exsanguination. All animal studies were performed during the same period $(9-11 \mathrm{am})$.

\section{Evaluation of white blood cell count and wet/dry ratio of lung tissue}

Blood was collected immediately after sacrifice and $30 \mu$ of samples were withdrawn to be dissolved in $570 \mu \mathrm{l}$ of glacial acetic acid for white blood cell count. The sera were separated by centrifugation at 2000rpm for 10 minutes at $4^{\circ} \mathrm{C}$ for further tests. The right lobe of lung tissue was obtained and weighed immediately and after 72 hours stored in oven at $60^{\circ} \mathrm{C}$ to determine wet/dry ratio of lung tissue.

\section{Analysis of Cytokine and Chemokine Levels}

The lower left lobe of lung was homogenized in $1.0 \mathrm{~mL}$ of cold phosphate buffered saline and preserved in iced bath before use. Lung homogenates were centrifuged at $12000 \mathrm{rpm}$ for 15 minutes at $4^{\circ} \mathrm{C}$. The supernants and the sera mentioned above were stored at $-70^{\circ} \mathrm{C}$ before treatments.

TNF- $\alpha$ and IFN- $\gamma$ in lung homogenates were determined with commercially available enzyme-linked immunosorbent assay kits according to the manufacturers' instructions (Shanghai Senxiong Corp.). Results were normalized to total amount of protein measured by BioRad protein Assay (BioRad Laboratories, Shanghai Medical School of Fudan University). 

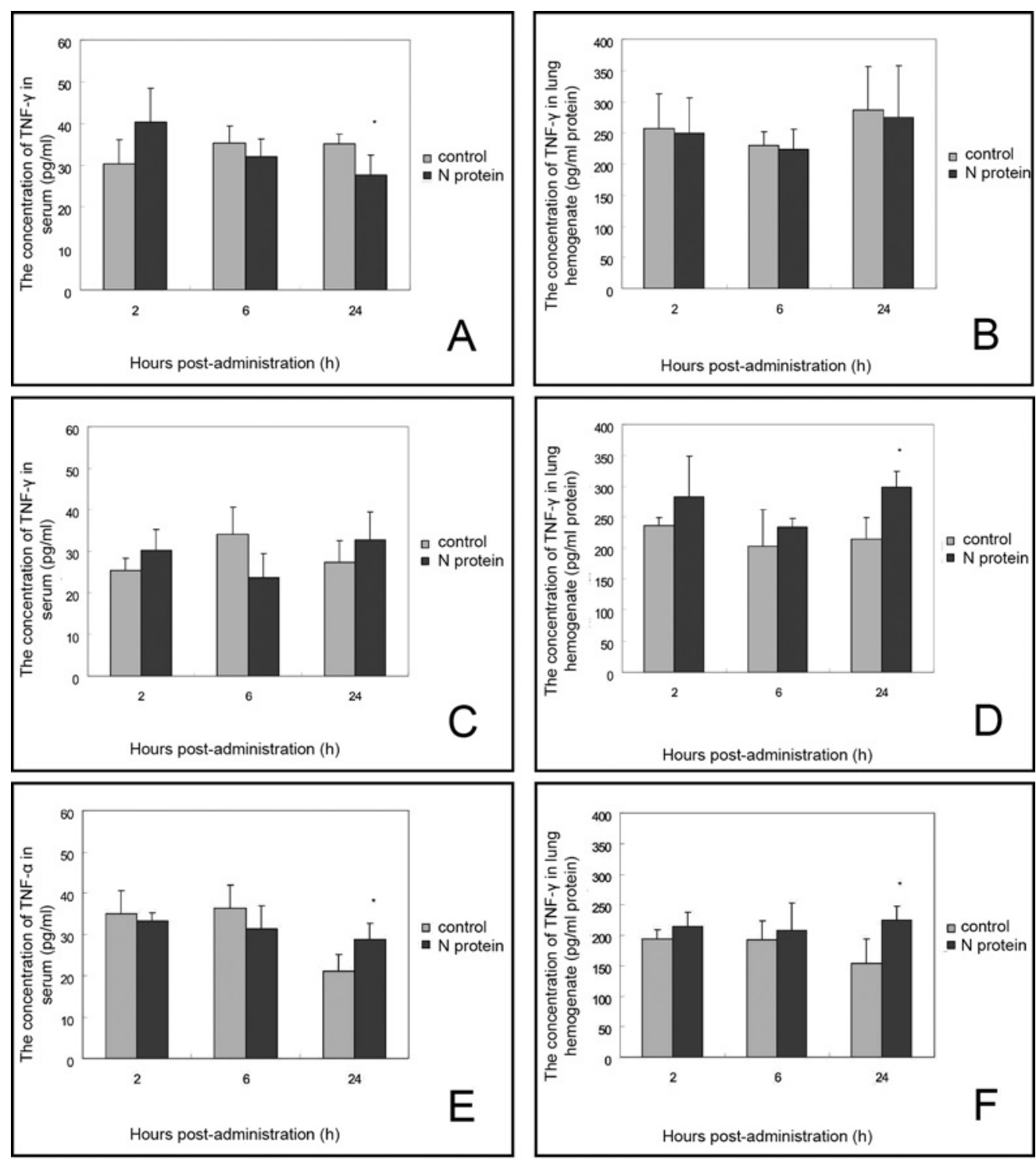

Fig 2. The concentration of IFN- $\gamma$ in sera and lung homogenate samples of $\mathrm{N}$-protein groups $(n=6)$ compared with control groups $(n=6)$. (A) The concentration of IFN- $\gamma$ in sera of weanling mice. (B) The concentration of IFN- $\gamma$ in homogenates of weanling mice. (C) The concentration of IFN- $\gamma$ in sera of young mice. (D) The concentration of IFN- $\gamma$ in homogenates of young mice. (E) The concentration of IFN- $\gamma$ in sera of adult mice. (F) The concentration of IFN- $\gamma$ in homogenates of adult mice. *Significant differences between N-protein groups and control groups, at $p<$ 0.05 .

TNF- $\alpha$ and IFN- $\gamma$ in sera were also determined with commercially available enzyme-linked immunosorbent assay kits in the same method as mentioned above.

\section{Histology}

The upper left lobe of lung was collected and fixed for histological assessment. The tissue was subsequently embedded with $10 \%$ (w/v) formalin solution that was buffered with phosphate buffered saline. Five-micron sections of lung were stained with hematoxylin and eosin and then evaluated by an experienced pathologist unaware of animal groupings using light microscopy. Changes in parenchyma were graded on a scale of 0 to 4 ( 0 , normal; 4 , severe) for congestion, edema, inflammation. After each of these was graded, the subscores were compiled for the total histopathological score (HPS). This total HPS assigns values from 0 to 12: the higher the score, the greater the inflammatory changes in the lung. ${ }^{[29]}$

\section{Statistical Analysis}

Data are expressed as mean \pm SEM. One-way Analysis of variance was used to determine statistical significance among multi groups and T' test was used for comparisons between two groups. Data were analyzed using the SPSS 13.0 system. $p$ value $<0.05$ was considered significant. .

\section{Results}

\section{Changes in leukocyte counts and lung injury index in infected mice}

Infection of young BALB/C mice with $\mathrm{N}$-protein of SARS-CoV $(6.07 \pm 2.38 \mathrm{millions} / \mathrm{ml})$ resulted in elevated levels of leukocytes count in peripheral blood compared with control group $(2.97 \pm 1.47 \mathrm{millions} / \mathrm{ml})$ when collected on 2 hours after administration $(p<0.05)$ (Table 1$)$. 
Table 3. Changes in lung parenchyma histopathology scores (Inflammation)

\begin{tabular}{|c|c|c|c|c|c|c|}
\hline & $\begin{array}{l}4 \text { weeks (weanling) } \\
\text { control }(n=6)\end{array}$ & N-protein $(n=6)$ & $\begin{array}{l}6 \text { weeks (young) } \\
\text { control }(n=6)\end{array}$ & N-protein $(n=6)$ & $\begin{array}{l}10 \text { weeks (adult) } \\
\text { control }(n=6)\end{array}$ & $\mathrm{N}$-protein $(\mathrm{n}=6)$ \\
\hline 2 hours & $1.33 \pm 0.82$ & $2.00 \pm 0.63$ & $1.33 \pm 0.82$ & $1.83 \pm 0.75$ & $1.00 \pm 0.89$ & $1.33 \pm 0.82$ \\
\hline 24 hours & $1.67 \pm 0.52$ & $2.33 \pm 0.82$ & $1.83 \pm 1.17$ & $2.00 \pm 0.63$ & $1.50 \pm 0.84$ & $2.83 \pm 0.75^{*}$ \\
\hline
\end{tabular}

Values are presented as mean \pm SD.

$*$ Significant differences between $\mathrm{N}$-protein groups and control groups, at $p<0.05$.

Table 4. Changes in lung parenchyma histopathology scores (Edema)

\begin{tabular}{lllllll}
\hline & $\begin{array}{l}\text { 4 weeks (weanling) } \\
\text { control }(\mathrm{n}=6)\end{array}$ & N-protein $(\mathrm{n}=6)$ & $\begin{array}{l}\text { 6 weeks (young) } \\
\text { control }(\mathrm{n}=6)\end{array}$ & N-protein $(\mathrm{n}=6)$ & $\begin{array}{l}10 \text { weeks }(\text { adult }) \\
\text { control }(\mathrm{n}=6)\end{array}$ & N-protein $(\mathrm{n}=6)$ \\
\hline 2 hours & $1.50 \pm 0.55$ & $2.33 \pm 0.82$ & $1.50 \pm 0.55$ & $2.00 \pm 0.63$ & $0.67 \pm 0.52$ & $1.17 \pm 0.41$ \\
6 hours & $1.33 \pm 0.82$ & $1.50 \pm 0.55$ & $1.67 \pm 0.52$ & $2.17 \pm 0.75$ & $1.17 \pm 0.75$ & $2.00 \pm 0.63$ \\
24 hours & $1.50 \pm 1.05$ & $2.33 \pm 1.21$ & $2.00 \pm 0.89$ & $2.16 \pm 0.75$ & $1.17 \pm 1.17$ & $3.00 \pm 0.89 *$ \\
\hline
\end{tabular}

Values are presented as mean $\pm \mathrm{SD}$.

*Significant differences between N-protein groups and control groups, at $p<0.05$.

The count in adult group $(59.0 \pm 67.4 \%)$ expanded after 24 hours in contrast to the weanling group $(-16.8 \pm$ $24.5 \%)$ and young group $(-25.2 \pm 27.3 \%)$ the count of which were slightly down $(p<0.05)$.

Although moderately elevated levels of W/D ratio in adult mice were observed following inoculation with $\mathrm{N}$ protein $(5.31 \pm 0.36)$ compared with control group $(4.66 \pm$ $0.25) 24$ hours later $(p<0.05)$, no significant differences were seen between control and infected mice of weanling and young groups.

\section{Changes in the concentration of TNF- $\alpha$}

To check the expression profiles of TNF- $\alpha$ in response to $\mathrm{N}$-protein of SARS-CoV in different ages, TNF- $\alpha$ was assayed in serum as well as homogenate samples. Compared with control group $(32.87 \pm 3.82 \mathrm{pg} / \mathrm{ml})$, the concentration of serum TNF- $\alpha$ increased in weanling group $(43.08 \pm 7.54 \mathrm{pg} / \mathrm{ml}) 6$ hours after exposure to $\mathrm{N}$-protein $(p=0.017)$. Likewise, the level in adult group (41.40 \pm $4.66 \mathrm{pg} / \mathrm{ml})$ also rose significantly compared with NS (normal saline) group $(28.32 \pm 4.53 \mathrm{pg} / \mathrm{ml})(p=0.008)$. (Figure 1) The level of serum TNF- $\alpha$ in weanling group was obviously increased after 6 hours while those in young group and adult group were slightly decreased ( $p=0.002, p=0.002$, respectively). However, the increase in the adult group was much higher than in the weanling group and young group ( $p=0.033, p=0.021$, respectively). (Figure 3)

Compared with the control group $(337.1 \pm 43.3 \mathrm{pg} / \mathrm{mg}$ protein), the concentration of homogenate TNF- $\alpha$ apparently decreased in the weanling group $(279.0 \pm 17.7 \mathrm{pg} /$ $\mathrm{mg}$ protein) 6 hours after exposure to $\mathrm{N}$-protein $(p=0.017)$. The levels of homogenate TNF- $\alpha$ after 2 hours $(416.6 \pm 41.7 \mathrm{pg} / \mathrm{mg}$ protein), 6 hours $(390.3 \pm 70.7 \mathrm{pg} / \mathrm{mg}$ protein), 24 hours $(447.0 \pm 24.7 \mathrm{pg} / \mathrm{mg}$ protein) were notably boosted compared with $2 \mathrm{~h}(281.2 \pm 53.2 \mathrm{pg} / \mathrm{mg}$ protein), $6 \mathrm{~h}(202.6 \pm 35.6 \mathrm{pg} / \mathrm{mg}$ protein $), 24 \mathrm{~h}$ (397.5 $\pm 29.8 \mathrm{pg} / \mathrm{mg}$ protein) NS groups respectively ( $p=0.001$, $p=0.003, p=0.043$, respectively). (Figure 1) The increase in homogenate TNF- $\alpha$ in the young group was higher than that of in the weanling group 2 hours after exposure to $\mathrm{N}$ protein $(p=0.002)$. After 6 hours, the increment in the young group was much higher than other two groups ( $p=0.001, p=0.002$, respectively). Besides, the change in adult group was also greater than that in weanling group $(p=0.011)$. (Figure 3$)$

\section{Changes in the concentration of IFN- $\gamma$}

To address the specificity of IFN- $\gamma$ profiles representing different stages of life-period following inoculation with $\mathrm{N}$-protein, we investigated the same categories of samples as TNF- $\alpha$. Compared with the control group (33.99 \pm $6.56 \mathrm{pg} / \mathrm{ml}$ ), the concentration of serum IFN $\gamma$ decreased in the young group $(23.56 \pm 5.85 \mathrm{pg} / \mathrm{ml}) 6$ hours after exposure to $\mathrm{N}$-protein $(p=0.029)$. In addition, the level in weanling group $(27.61 \pm 4.93 \mathrm{pg} / \mathrm{ml})$ also decreased compared with NS group $(35.12 \pm 2.47 \mathrm{pg} / \mathrm{ml})$ while the adult group $(28.89 \pm 3.78 \mathrm{pg} / \mathrm{ml})$ was raised compared with the NS group $(21.22 \pm 4.01 \mathrm{pg} / \mathrm{ml}) \quad(p=0.034$, $p=0.032$, respectively). (Figure 2) The increase in serum IFN- $\gamma$ in weanling the group was considerably higher than that of in the young group after 6 hours $(p=0.001)$. Nevertheless, the increase in both young group and adult group was much higher than in weanling the group ( $p=0.019, p=0.002$, respectively). (Figure 3 )

The concentration of homogenate IFN- $\gamma$ was raised in the young $(298.9 \pm 26.1 \mathrm{pg} / \mathrm{mg}$ protein $)$ and adult groups $(225.0 \pm 22.2 \mathrm{pg} / \mathrm{mg}$ protein) 24 hours after exposure to $\mathrm{N}$ - 

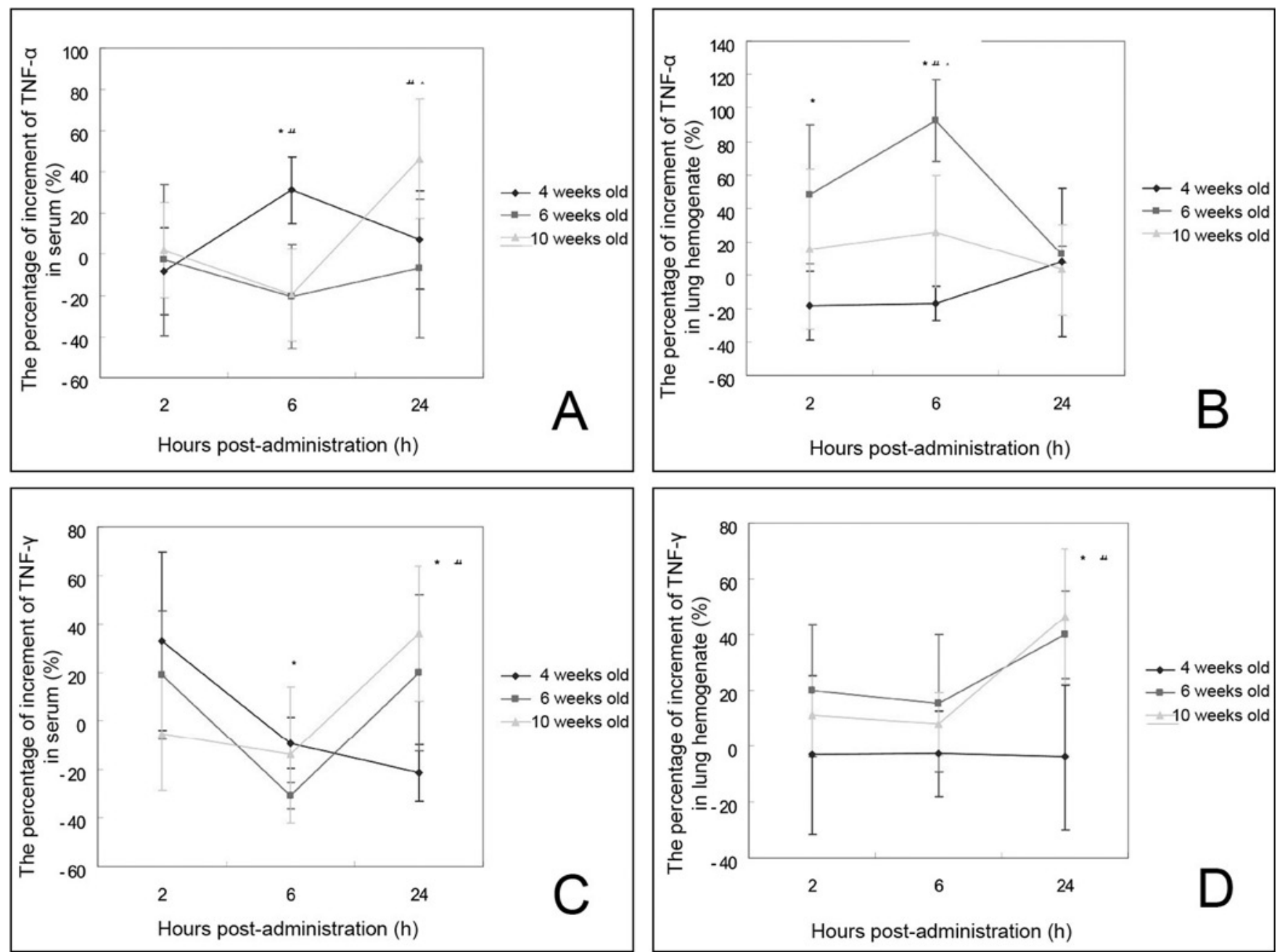

Fig 3. The percentage increase in cytokines in sera and lung homogenate samples comparing N-protein groups $(n=6)$ with control groups $(n=6)$. (A) The percentage increase in TNF- $\alpha$ in sera comparing N-protein groups with control groups. (B) The percentage increase in TNF- $\alpha$ in homogenates comparing N-protein groups with control groups. (C) The percentage increase in IFN- $\gamma$ in sera comparing N-protein groups with control groups. (D)

The percentage increase in IFN- $\gamma$ in homogenates comparing N-protein groups with control groups.

* Significant differences between young groups and weanling groups, with $p<0.05$.

\# Significant differences between adult groups and weanling groups, with $p<0.05$.

$\Delta$ Significant differences between adult groups and young groups, with $p<0.05$.

protein compared with young control group (213.3 \pm $35.0 \mathrm{pg} / \mathrm{mg}$ protein) and adult control group (153.5 \pm $39.9 \mathrm{pg} / \mathrm{mg}$ protein) respectively $(p=0.008, p=0.020$, respectively). (Figure 2) The increase in homogenate IFN- $\gamma$ in both young and adult groups was much higher than that in the weanling group after 24 hours $(p=0.005, p=0.017$, respectively). (Figure 3)

\section{Histology}

Histopathological changes were scored for congestion, inflammation and edema. (Table 2,3,4). The scores in all categories were higher in the N-protein groups as compared with the control groups in weanlings just 2 hours after intranasal inoculation of $\mathrm{N}$-protein and recurrence was also found at 24 hours after a period of relief. In addition, progressively increased scores were displayed at 6 hours in the young. However, statistically significant differences were not found in weanling and young except for the score for congestion at 6 hours in the young.

At an early stage, the scores were slightly higher in Nprotein groups versus the control groups at 2 hours in adult but they showed a strong increasing trend over time. The scores in all categories were significantly higher at 24 hours.

Total histopathological scores were calculated (Table 5), resulting in remarkably higher scores for the N-protein versus control groups at 24 hours in the adult. A statistically higher score at 6 hours in the young was also seen (Figure 4). 

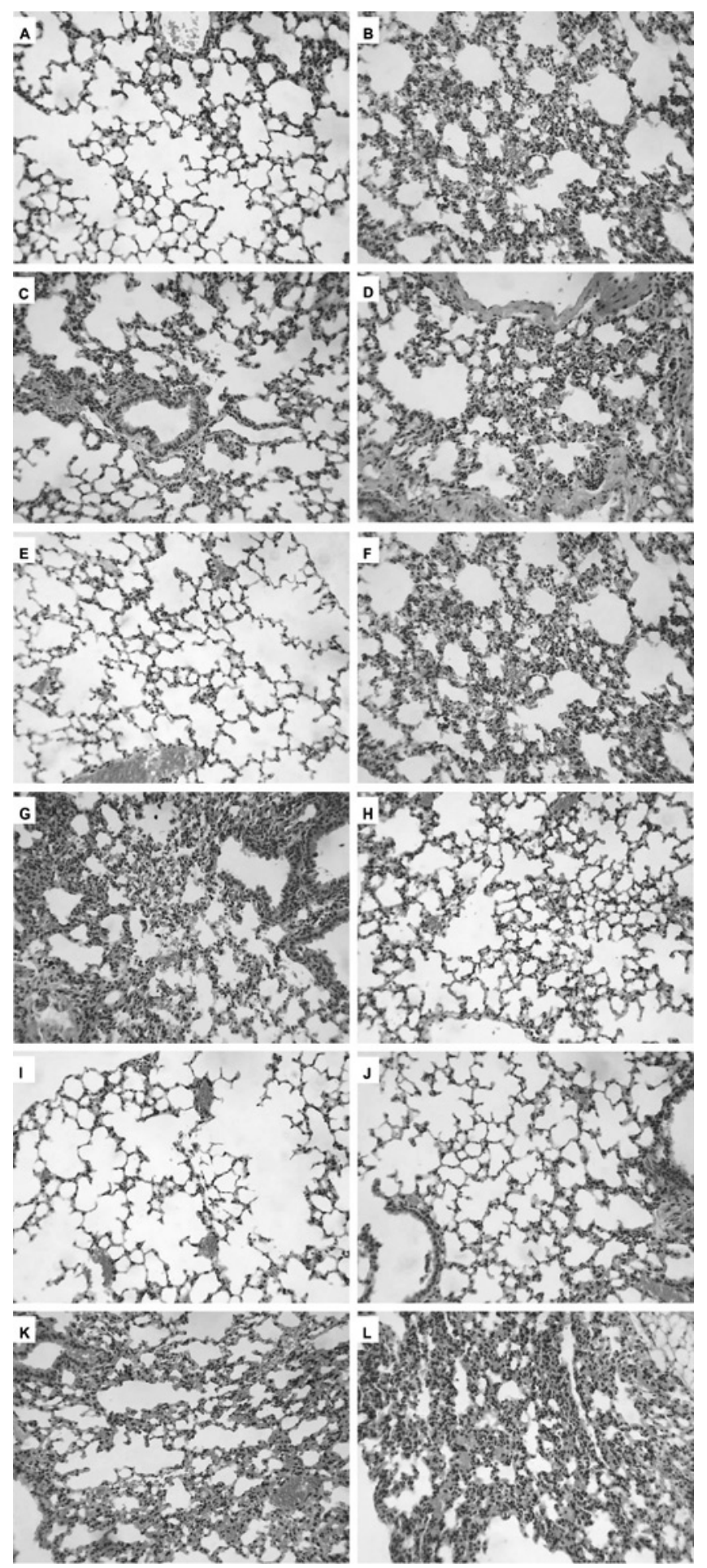

Fig 4. Histopathological changes in lungs from SARS-CoV N-protein infected mice (hematoxylin and eosin Stain, original magnifications $\times 200$ ). (A) Control groups of weanling mice. (B) 2 hours after inoculation of weanling mice with N-protein. (C) 6 hours after inoculation of weanling mice with N-protein. (D) 24 hours after inoculation of weanling mice with $\mathrm{N}$-protein. (E) Control groups of young mice. (F) 2 hours after inoculation of young mice with N-protein. (G) 6 hours after inoculation of young mice with N-protein. $(\mathrm{H}) 24$ hours after inoculation of young mice with $\mathrm{N}$-protein. (I) Control groups of adult mice. (J) 2 hours after inoculation of adult mice with $\mathrm{N}$-protein. (K) 6 hours after inoculation of adult mice with $\mathrm{N}$-protein. (L) 24 hours after inoculation of adult mice with $\mathrm{N}$-protein.

\section{Discussion}

Our goal was to examine the changes in the early stage of lung inflammation caused by $\mathrm{N}$ protein of SARS-CoV among different age groups. BALB/c mice, small and accessible, infected with N-protein of SARS-CoV which have been evaluated extensively at the immunological level by several labs as a possible animal model for SARS $[18,19,20]$. It seems that the route of inoculation was a key factor to demonstrate SARS-CoV replication in mice. Subbarao et al. ${ }^{[20]}$ demonstrated that SARS-CoV does infect BALB/c mice by intranasal inoculation. Mice exhibited mild and focal peribronchiolar mononuclear inflammatory infiltrates, with no significant pathology in other organs. A previous study ${ }^{[21]}$ confirmed that animals showed acute lung injury 6 hours after inoculating with $\mathrm{N}$ protein, which suggested that mice infected by N-protein can mimick the immunopathological processes of SARS in the short term. In our study, inflammatory and histopathological changes in lungs were present in some animals just 2 hours following administration. In general, humans exhibit more mature lungs at birth than rodents. Alveolarization in rodents occurs exclusively from Days 4 to 14 after birth and thoracic growth and alveolarization persist throughout life. Mice are weaned at approximately 4 weeks old when the alveolar wall has been formed and testes of male mice have dropped to the scrotum at about 50 days old ${ }^{[30,31]}$. In our study, BALB/C mice at the age of 4,6,10 weeks old were chosen in analogy to the periods of childhood, adolescent and adult in human respectively.

Epidemiological studies of the SARS outbreak of 2003 to 2004 showed that advanced age was a risk factor for an adverse outcome from SARS ${ }^{[27,28]}$. Lung inflammation caused by SARS-CoV is likely a complex pathophysiological process involving inflammatory cytokines released from activated macrophages in alveoli, leading to immune system dysregulation. The predominant pathology in the lungs of patients infected with SARS-CoV has been demonstrated as diffuse alveolar damage (DAD) ${ }^{[32]}$. In this study, histopathological analysis of adult male BALB/C mice after N-protein infection showed progressive inflammatory reactions, especially pulmonary edema, in accordance with a moderately $(\sim 13 \%)$ elevated level of W/D ratio at 24 hours. Loss of cilia, denudation of the bronchiolar epithelium, and luminal deposition of fibrin provided evidence of more severe injury to the bronchiolar epithelium in adult than in weanling and young mice. Interestingly, we observed that pulmonary inflammation and congestion occurred immediately after intranasal inoculation of N-protein in weanling groups and recurrence was found at 24 hours after a period of relief. We also found lung injury became progressively worse at 6 hours in young groups, but it lessened after that. However, no significant differences in either W/D ratio and histopathological scores were seen between control and infected mice of weanling and young groups except at 6 hours in young. Some reports ${ }^{[25]}$ in- 
Table 5. Changes in lung parenchyma histopathology scores (Total HPS)

\begin{tabular}{|c|c|c|c|c|c|c|}
\hline & $\begin{array}{l}4 \text { weeks (weanling) } \\
\text { control }(n=6)\end{array}$ & N-protein $(n=6)$ & $\begin{array}{l}6 \text { weeks (young) } \\
\text { control }(n=6)\end{array}$ & N-protein $(n=6)$ & $\begin{array}{l}10 \text { weeks (adult) } \\
\text { control }(n=6)\end{array}$ & $N$-protein $(n=6)$ \\
\hline 2 hours & $4.33 \pm 1.86$ & $6.50 \pm 1.64$ & $4.00 \pm 1.67$ & $5.83 \pm 1.94$ & $2.50 \pm 1.97$ & $3.83 \pm 1.83$ \\
\hline 24 hours & $4.67 \pm 1.97$ & $7.00 \pm 2.76$ & $5.83 \pm 2.93$ & $6.33 \pm 1.86$ & $4.00 \pm 2.53$ & $8.50 \pm 2.17 *$ \\
\hline
\end{tabular}

Values are presented as mean \pm SD.

*Significant differences between N-protein groups and control groups, at $p<0.05$.

dicated that the inflammation of lung would become aggravated again in some patients, being named the "second peak". One possible explanation was attribueted to the secondary virema. Others have proposed that the secondary immune response related to the infection of virus may play an important role ${ }^{[26]}$. Mice in weanling groups underwent similar processes which were different from the other two groups, suggesting acute immunopathological development of disease at an early stage in the weanling. Further time points need to be assessed to investigate whether older groups have the same processes over time.

Immunopathological injury of host cells triggered by the immune response to virus plays a key role in the pathogenesis of virus infections. Many cytokines released from activated immune cells not only take part in the process of antiviral immune response, but are also involved in cell damage and development of organ dysfunction. Pak $\mathrm{C}$ et al. reported that TNF- $\alpha$ were only mildly raised at the initial phase of the illness in children [16]. Interestingly, the progression levels of TNF- $\alpha$ in serum of adult SARS patients were reported by the Beijing group of National Research Project for SARS ${ }^{[15]}$. Our results showed the levels of TNF- $\alpha$ in focal lung tissue at young groups were much higher than in the other two groups at the early stage of disease while young groups presented a relatively severe transient circumscribed lung injury only at 6 hours. Although adult groups underwent a progressive lung inflammation in the acute phase accompanied by raised levels of TNF- $\alpha$ in serum, no significant changes in lung TNF- $\alpha$ level were reported simultaneously. This raised the questioned of whether the measurement of TNF- $\alpha$ level reflected the severity of lung injury at the early stage of SARS.

Disequilibrium in immunological systems caused by imbalance of Th1/Th2 cytokines is probably one of the critical pathogenic mechanisms of SARS. It has been proven that the levels of IFN- $\gamma$ and some proinflammatory cytokines were significantly advanced in the early stage of SARS and even decreased in the convalescence stage ${ }^{[13,14]}$. In our study, adult SARS infected BALB/c mice showed elevated levels of IFN- $\gamma$, suggesting that the proinflammatory cytokine response may be responsible for SARS-associated events ${ }^{[24]}$. However, IFN- $\gamma$ levels in weanling and young groups have no obvious association with lung inflammation. Possible reasons proposed include that weanling mice were not able to mount a "hei- ghtened" mature immune response as seen in adults during the immune deregulation phase of SARS and thus less organ damage ensued with its associated morbidity and mortality ${ }^{[22]}$. It was also confirmed by our research that the increment of W/D ratio in weanling groups was not as significant as that of in adult groups. In addition, Leung $\mathrm{CW}$, et al. ${ }^{[23]}$ posed the viewpoint that children in general presented with less comorbidity than adults and this may contribute to low mortality in children. Moreover, the roles of other cytokines except TNF- $\alpha$ and IFN$\gamma$ in the immunopathological processes of disease, especially at early stages, remained undetermined because of the limitation of the amount of specimen.

In conclusion, our study supports the observation that adult mice do have progressively greater immune reactions than weanling and adolescent animals over time. The relative immaturity of the immune system in weanlings may confer benefit leading to less impairment of lung function. However, the measurement of TNF- $\alpha$ and IFN- $\gamma$ levels seemed not to be indicative of the severity of lung injury at the early stage of disease.

Acknowledgements. This study was supported by grants from the Specialized Research Fund for the Doctoral Programme of China (No. 20050246047), the Key Project of Science and Technology Commission of Shanghai Municipality (No.05JC14015) and Shanghai Leading Academic Discipline Project (Project Number: B115).

\section{References}

[1] Li AM, Ng PC. Severe acute respiratory syndrome (SARS) in neonates and Children. Arch Dis Child Fetal Neonatal Ed 2005; 90: $461-465$.

[2] Ksiazek TG, Ersman D, Goldsmith CS, Zaki SR, Peret T, Emery S, et al. A novel coronavirus associated with severe acute respiratory syndrome. N Engl J Med 2003; 348: 1953-1966.

[3] Peng H, Yang LT, Wang LY, Li J, Huang J, Lu ZQ, et al. Long-lived memory $\mathrm{T}$ lymphocyte responses against SARS coronavirus nucleocapsid protein in SARS-recovered patients. Virology 2006; 351: $466-475$.

[4] Hiscox JA, Wurm T, Wison L, Britton P, Cavanagh D, Brooks G. The coronavirus infectious bronchitis virus nucleoprotein localizes to the nucleolus. J Virol 2001; 75: 506-512.

[5] Collisson EW, Pei J, Dzielawa J, Seo SH. Cytotoxic T lymphocytes are critical in the control of infectious bronchitis virus in poultry. Dev Comp Immunol 2000; 24: 187-200.

[6] Zhu MS, Pan Y, Chen HQ, Shen Y, Wang XC, Sun YJ, et al. Induction of SARS-nucleoprotein-specific immune response by use of DNA vaccine. Immunol Lett 2004; 92: 237-243. 
[7] Jin K, Chong X, Chen Z, Chen Z, Kang Y, Ma Y, et al. Induction of Th1 type response by DNA vaccinations with $\mathrm{N}, \mathrm{M}$, and $\mathrm{E}$ genes against SARS-CoV in mice. Biochem Biophys Res Commun 2005; 328: 979-986.

[8] Zhu YJ, Chen WB, eds. Respiratory medicine. Beijing: People's Medical Publishing House; 2003: 1396-1422.

[9] Millar AB, Foley NM, Singer M, Johnson NM, Meager A, Rook GA. Tumor necrosis factor in bronchopulmonary secretions of patients with adult respiratory distress syndrome. Lancet 1989; 2: $712-714$.

[10] Tracey KJ, Beutler B, Lowry SF, Merryweather J, Wolpe S, Milsark IW, et al. Shock and tissue injury induced by recombinant human cachectin. Science 1986; 234: 470-474.

[11] Cheung CY, Poon LL, Lau AS, Luk W, Lau YL, Shortridge KF, et al. Induction of proinflammatory cytokines in human macrophages by influenza A (H5N1) viruses: a mechanism for the unusual severity of human disease? Lancet 2002; 360: 1831-1837.

[12] Van Reeth K, Van Gucht S, Pensaert M. In vivo studies on cytokine involvement during acute viral respiratory disease of swine: troublesome but rewarding. Vet Immunol Immunopathol 2002; 87: $161-168$.

[13] Wong CK, Lam CW, Wu AK, Ip WK, Lee NL, Chan IH, et al. Plasma inflammatory cytokines and chemokines in severe acute respiratory syndrome. Clin Exp Immunol 2004; 136: 95-103.

[14] Zhang Y, Li J, Zhan Y, Wu L, Yu X, Zhang W, et al. Analysis of Serum Cytokines in Patients with Severe Acute Respiratory Syndrome. Infect Immun 2004; 72: 4410-4415.

[15] Beijing Group of National Research Project for SARS. Dynamic changes in blood cytokine levels as clinical indicators in severe acute respiratory syndrome. Chin Med J (Engl) 2003; 116; 1283 1287.

[16] Ng PC, Lam CW, Li AM, Wong CK, Cheng FW, Leung TF, et al. Inflammatory cytokine Profile in children with severe acute respiratory syndrome. Pediatrics 2004; 113(1 Pt 1): e7-14.

[17] Ng PC, Leung CW, Chiu WK, Wong SF, Hon EK. SARS in Newborns and Children. Biol Neonate 2004; 85: 293-298.

[18] Liu BH, Wu DL, Zhan DW, Qin ED, Zhu QY. Study on the animal model for Severe Acute Respiratory Syndrome. Acta Micro Sinica 2004; 44: 711-716.

[19] Roberts A, Deming D, Paddock CD, Cheng A, Yount B, Vogel L, et al.A Mouse-Adapted SARS-Coronavirus Causes Disease and Mortality in BALB/c Mice. PLoS Pathog 2007; 3: e5.
[20] Subbarao K, J McAuliffe, LVogel, G Fahle, S Fischer, K Tatti, et al. Prior infection and passive transfer of neutralizing antibody prevent replication of severe acute respiratory syndrome coronavirus in the respiratory tract of mice. J Virol 2004; 78: 3572-3577.

[21] Hao D, He LX, Qu JM, Pan J, Hu BJ, Zhang J, et al. A study of mechanism of pulmonary inflammation caused by SARS-CoVand effects of glucocorticoids on it. Chin J Internal Med 2005; 44: 890 893.

[22] Hon KL, Leung CW, Cheng W, et al. Clinical presentations and outcome of severe acute respiratory syndrome in children. Lancet 2003; 361: 1701-1703.

[23] Leung CW, Kwan YW, Ko PW, et al. Severe acute respiratory syndrome among children. Pediatrics 2004; 113: e535-e543.

[24] Roberts A, C Paddock, L Vogel, E Butler, S Zaki, K Subbarao. Aged BALB/c mice as a model for increased severity of severe acute respiratory syndrome in elderly humans. J Virol 2005; 79: $5833-5838$.

[25] Ne LG, Li HC, Jue CL, Wang GF, Ma J, et al. The clinical presentation and treatment of second-peak in SARS. Beijing University Acta 2003; 35: 553-555.

[26] Ma J, Li N, Jue CL, Li HC, Ne LG, Wang GF, et al. The character of radiography and dynamic variation in SARS. Beijing University Acta 2003; 35(supp): 38-40.

[27] Chan JW, Ng CK, Chan YH, Mok TY, Lee S, Chu SY, et al. Short term outcome and risk factors for adverse clinical outcomes in adults with severe acute respiratory syndrome (SARS). Thorax 2003; 58: 686-689.

[28] Tsui PT, Kwok ML, Yuen H, Lai ST. Severe acute respiratory syndrome: clinical outcome and prognostic correlates. Emerg Infect Dis 2003; 9: 1064-1069.

[29] Cimolai N, Taylor GP, Mah D, Morrison BJ. Definition and application of a histopathological scoring scheme for an animal model of acute Mycoplasma pneumoniae pulmonary infection. Microbiol. Immunol. 1992; 36: 465-478.

[30] American Thoracic Society. Mechanisms and limits of induced postnatal lung growth. Am J Respir Crit Care Med. 2004; 170: 319-343.

[31] Thurlbeck WM. Lung growth and alveolar multiplication. Pathobiol Annu. 1975; 5: 1-34.

[32] Franks TJ, Chong PY, Chui P, Galvin JR, Lourens RM, Reid AH, et al. Lung pathology of severe acute respiratory syndrome (SARS): a study of 8 autopsy cases from Singapore. Hum Pathol. 2003; 34: 743-748.

\section{To access this journal online:} www.birkhauser.ch/ir 